\title{
O ESTADO DE EXCEÇÃO NA ERA DA BIOPOLÍTICA: O JOGO DA LEGITIMAÇÃO PELO DIREITO
}

\author{
Gerson Faustino Rosa ${ }^{1}$ \\ Carolina Noura de Moraes Rêgo ${ }^{2}$
}

\begin{abstract}
Resumo: O presente trabalho propõe uma reflexão acerca do papel exercido pelo Estado de Direito na vida dos cidadãos, em especial quando esse Estado vale-se do liberalismo como arte de governar e passa a ser o gestor da "felicidade" humana. Durante essa reflexão, faz-se um breve excurso nas obras de Giorgio Agamben e Michel Foucault, analisando os conceitos de Estado de exceção e de biopolítica, respectivamente desenvolvido por eles. Regressa-se à forma de exclusão sofrida pelo homo sacer, conforme o pensamento de Agamben, a fim de compará-lo ao "bandido" dos nossos dias, também excluído da sociedade no mais das vezes. Por fim, expõe-se o papel do Direito do Estado, utilizado como instrumento de legitimação da crueldade e de interesses que não condizem com a vontade geral. Empregar-se-á, para tanto, os métodos lógico-dedutivo e indutivoargumentativo, através de análises fundamentais e qualitativas, tendo como recursos bibliografia nacional e estrangeira.
\end{abstract}

Palavras-chave: Estado. Direito. Biopolítica. Homo Sacer. Estado de Exceção.

Résumé: Cet article propose une réflexion sur le rôle joué par la primauté du droit dans la vie des citoyens, en particulier lorsque cet État utilise le libéralisme avec l'art de gouverner et s'avère être le générateur du «bonheur» humain. Au cours de cette réflexion, un bref extrait est fait dans les œuvres de Giorgio Agamben et Michel Foucault, analysant les concepts d'état d'exception et de biopolitique, respectivement développés par eux. Il revient à la forme d'exclusion souffert par l'homo sacer, selon la pensée d'Agamben, afin de le comparer au «bandit» de notre époque, également exclu de la société le plus souvent. Enfin, le rôle de la loi de l'État, utilisé comme un instrument pour légitimer la cruauté et les intérêts qui ne correspondent pas à la volonté générale, est exposé. Pour cela, les méthodes logico-déductive et inductive-argumentative seront utilisées, à travers des analyses fondamentales et qualitatives, ayant comme ressources de la bibliographie nationale et étrangère.

Mots-clés: État. Droit. Biopolitique. Homo Sacer. État d'Exception.

\footnotetext{
${ }^{1}$ Professor de Direito Penal e Ciência Política nos cursos de pós-graduação e de graduação da Universidade Estadual de Maringá-PR (UEM); Professor de Direito Penal e coordenador da Pós-graduação em Ciências Penais na UNOESTE de Presidente Prudente-SP; Professor credenciado junto à Escola Superior de Educação em Direitos Humanos do Estado do Paraná (ESEDH); Professor de Direito Penal nos cursos de pós-graduação da Escola Superior da Advocacia (ESA), da UNIFAMMA, das Faculdades Maringá e da Faculdade Integrado de Campo Mourão-PR; Pesquisador do CNPq, com experiência na área do Direito, com ênfase em Direito Penal e Política Criminal, atuando principalmente nos seguintes temas: expansão e modernização do Direito Penal, parte geral, parte especial do Código Penal brasileiro e terrorismo. Doutorando em Direito pela Faculdade de Direito de São Paulo-SP (FADISP), Mestre em Ciências Jurídicas pelo Centro Universitário de Maringá-PR (2014), pós-graduado em Ciências Penais pela Universidade Estadual de Maringá - PR (2011), pós-graduado em Direito Penal e Processual Penal pela Universidade Gama Filho - RJ (2008), graduado em Direito pela Associação Educacional Toledo de Presidente Prudente - SP (2007). Instituição: Universidade Estadual de Maringá, Paraná. Brasil. Email: gersonfaustinorosa@gmail.com

${ }^{2}$ Doutoranda em Direito pela Fadisp, mestre em História pela UnB. Advogada. Instituição: FADISP - Faculdade Autônoma de Direito. Brasil. E-mail: carolnoura@gmail.com
} 


\section{INTRODUÇÃO}

Muito se tem discutido acerca da o real papel do Direito na regulação da vida humana, confrontando sua função de pacificação social ao mister exercido pelo Ordenamento Jurídico no liberalismo enquanto arte de governar, onde passa a ser usado, em verdade, como um dispositivo de racionalização da vida humana.

Para tanto, far-se-á um excurso nas obras de Giorgio Agamben e Michel Foucault, abordando, respectivamente, a teoria do Estado de exceção e a noção de biopolítica, iniciando pelo testemunho do deixar morrer e a implicação do direito nas formas de vida ${ }^{3}$. Daí falar-se que o campo de concentração é o mais absoluto espaço biopolítico jamais realizado, no qual o poder não tem diante de si senão a pura vida sem qualquer mediação ${ }^{4}$.

O resto de Auschwitz significa a solapa da própria eficácia do dizer e, por isso mesmo, institui a verdade de sua fala. E este "resto" como aquilo que, no testemunho, encoberta a própria eficácia do dizer e, por isso mesmo, institui a verdade de sua fala.

Nos campos de concentração há uma devastadora ausência de normas, a administração nazista estabelece uma "ordem” tão rígida quanto aleatória, os presos são entregues a um arbítrio implacável. A dificuldade tem a ver com a própria estrutura do testemunho. Um dos equívocos do campo é a confusão entre categorias éticas e categorias jurídicas ${ }^{5}$.

O testemunho traz lacunas de identidade de quem testemunha e de credibilidade de quem testemunha. Não é possível dizer a verdade, testemunhar a partir de fora.

E logo surge a vergonha de ser sobrevivente, pois aquele que sobrevive no campo, sente-se culpado por presenciar a morte dos demais, que talvez tenham morrido em seu lugar. E a outra face da vergonha de quem sobreviveu é a exaltação da simples sobrevivência como tal. A sobrevivência é uma experiência dotada de uma estrutura definida, nem fortuita, nem regressiva, nem amoral e ao mesmo tempo, torna visível tal estrutura.

De fato, não é certo que o sentimento de culpa por viver em lugar de outrem seja a explicação correta para a vergonha do sobrevivente. Ocorre que, ter vergonha significa ser entregue a um inassumível. Não é algo exterior, mas interior. Daí dizer que o termo "sobreviver" contém uma ambiguidade impossível de eliminar, pois supõe uma remissão a algo ou a alguém, a que se

\footnotetext{
${ }^{3}$ Inicia-se a partir do testemunho, uma breve análise da obra de Giorgio Agamben, que nasceu em 1942, é um filósofo italiano, também formado em Direito, autor de obras que percorrem temas que vão da estética à política. Seus trabalhos mais conhecidos incluem sua investigação sobre os conceitos de estado de exceção e homo sacer (AGAMBEN, Giorgio. O que resta de Auschwitz: o arquivo e a testemunha (Homo Sacer III). São Paulo: Boitempo, 2008).

${ }^{4}$ Cf. AGAMBEN, Giorgio, Homo Sacer I: poder soberano e vida nua. São Paulo: Boitempo, 2008.

${ }^{5}$ AGAMBEN, Giorgio. O que resta de Auschwitz: o arquivo e a testemunha (Homo Sacer III). São Paulo: Boitempo, 2008, p. 28.
} 
sobrevive. Por isso a assertiva de Agamben, de que "o homem é aquele que pode sobreviver ao homem"6.

Assim, "o fazer viver e o deixar morrer" marcam o biopoder, transformando a estatização do biológico e o cuidado com a vida no próprio objetivo primário. É a biopolítica do século XX: nem a vida, nem a morte, mas a mera produção de uma sobrevivência modulável ${ }^{7}$. Tem-se então, cada vez mais, uma política "da" vida, e não uma política "para" a vida. É pois uma política como recurso funcional para a eficiência institucional, onde a vida se torna meio da política entendida como gestão, que torna-se uma fim. Uma absurda inversão de valores.

Trata-se no caso do homem de separar cada vez mais a vida orgânica da vida animal, o nãohumano do humano, o "muçulmano" da testemunha, a vida vegetal mantida em funcionamento mediante as técnicas de reanimação da vida consciente, até alcançar um "ponto-limite" que, assim como as fronteiras geopolíticas, é essencialmente móvel e se desloca segundo o progresso das tecnologias científicas e políticas ${ }^{8}$.

O contexto é, portanto, de uma vida que se vive sem viver, de "fazer viver e deixar morrer", de uma vida sem sentido em que o sujeito simplesmente se "a-sujeita", ficando sempre a serviço de ou à disposição... Sendo que as instituições regulam a forma de vida. Eis a similaridade com a vida nos campos de concentração9 . O testemunho não garante a verdade fatual do enunciando conservado no arquivo, mas a sua não-arquivabilidade, a sua exterioridade.

Utilizar-se-á, no presente trabalho, o método lógico-dedutivo, a fim de compreender o paralelo traçado por Agamben entre a vida no Estado de Direito e a vida no campo de concentração, bem como, a denúncia foucaultiana de mera gestão da vida biológica pelo Estado. Empregar-se-á ainda, o método indutivo-argumentativo, demonstrando a implicação desses estudos na atual conjuntura do Estado de Direito. Valer-se-á, para tanto, de análises fundamentais e qualitativas, tendo como recursos bibliografias nacional e estrangeira.

\section{O MUÇULMANO E A CRUELDADE HUMANA: UM RETORNO AO HOMO SACER}

\footnotetext{
${ }^{6}$ Ibidem, p. 135.

${ }^{7} \mathrm{O}$ simples nascimento e a exposição ao poder do Estado (vida nua) uniram-se no "sujeito soberano", fundamento do Estado moderno. Não é o homem como sujeito político, livre e consciente (vide: AGAMBEN, Giorgio. $O$ que resta de Auschwitz: o arquivo e a testemunha (Homo Sacer III). São Paulo: Boitempo, 2008). E esse "sujeito", que inexistia na antiguidade e na idade média, nasce no século XVIII, com o surgimento do Estado moderno, quando, segundo Foucault, Thomas Hobbes, como um mordomo, abre as porta do deserto (FOUCAULT, Michel. Nascimento da biopolítica: curso dado no Collège de France (1978-1979). São Paulo: Martins Fontes, 2008).

${ }^{8}$ Mente e corpo são inseparáveis (FOUCAULT, Michel. op. cit.).

9 AGAMBEN, Giorgio. O que resta de Auschwitz: o arquivo e a testemunha (Homo Sacer III). São Paulo: Boitempo, 2008, p.156.
} 
A partir do "bando", dos grupos gentílicos primitivos - de onde se transpõe a matriz jurídicoobrigacional do débito e do crédito, e portanto, o apanágio do processo civilizatório - tem-se a base da organização social, e por consequência, o elemento originário da política. E diante do descumprimento da obligatio por um de seus membros, o grupo gentílico o expulsava, quebrando o ideal de solidariedade existente, não havendo, a partir do abandono, direitos e obrigações entre o grupo e o proscrito, que era excluído. O indivíduo banido da comunidade passa a ser odiado como um inimigo, que passa a viver à mercê da violência e do arbítrio de indivíduos e grupos ${ }^{10}$.

Contornos semelhantes, encontramos no Friedlos, do Direito germânico e no Homo Sacer do Direito romano, ambos condenados a viver em proscrição religiosa e civil, completamente excluídos da comunidade humana e sujeitos à vingança divina ${ }^{11}$.

O homo sacer é, segundo Agamben, a figura jurídico-política pela qual uma pessoa, ao ser proclamada sacer (sagrado), era legalmente excluída do Direito e, consequentemente, da política da cidade. Tal condição de sacer impedia que ela pudesse ser legalmente morta (sacrificada), porém qualquer um poderia matá-la sem que a lei o culpasse por isso ${ }^{12}$. O homo sacer é a vida abandonada pelo Direito. É o que Walter Benjamin denominou de pura vida nua ${ }^{13}$.

A particularidade do homo sacer é que ele é incluído pela exclusão e excluído de forma inclusiva. Esta figura paradoxal captura a vida humana pela exclusão ao mesmo tempo em que a inclui pelo abandono. É uma vida matável por estar fora do Direito, mas por isso mesmo ela não pode ser condenada juridicamente. Está exposta à vulnerabilidade da violência por ser desprovida de qualquer direito, sendo que tal vulnerabilidade se deriva de um ato de direito que a excluiu ${ }^{14}$.

O homo sacer é um conceito-limite do Direito romano que delimita o limiar da ordem social e da vida humana. Nele transparece a correlação entre a sacralidade e a soberania. Ambas são estruturas originárias do poder político e jurídico ocidentais porque revelam os dois personagens que estão fora e acima da ordem: o homo sacer e o soberano. O homo sacer não só mostra a fragilidade da vida humana abandonada pelo Direito, mas também, e mais importante, revela a

\footnotetext{
${ }^{10}$ GARBELLINI CARNIO Henrique; GUERRA FILHO, Willis Santiago. Teoria política do direito: a expansão política do direito. $2^{\mathrm{a}}$. ed. São Paulo: Revista dos Tribunais, 2013, p. 74-85.

${ }^{11}$ Ibidem, p. 74-85.

${ }^{12}$ Agamben promove incursão epistêmica no Direito e na Política a partir do ser humano (homo sacer), com objetivo de captar uma tensão muito pouco percebida pela qual o Direito e a Política ocidentais existem correlacionadas com a captura do humano. Neste ponto, Agamben dissente de Foucault ao afirmar que a biopolítica não é uma característica da modernidade, mas algo inerente à política ocidental desde suas origens. Embora concorde com Foucault que a modernidade expandiu a biopolítica de forma capilar ao tentar governar de forma útil e produtiva, objetivando-a para tanto como um mero recurso natural (AGAMBEN, Giorgio. Homo Sacer: o poder soberano e a vida nua I. Belo Horizonte: UFMG, 2002, p. 173).

13 RUIZ, Castor M. M. Bartolomé. A exceção jurídica na biopolítica moderna. Disponível em: http://www.ihuonline.unisinos.br/index.php?option=com_content\&view=article\&id=4044\&secao=371. Acesso em: 18 abril, 2017.
}

${ }^{14}$ GIACOIA JUNIOR. Oswaldo. Aula inaugural: sobre direitos humanos na era da bio-politica, p. 289. vol.12,nº2, Rio de Janeiro,2019.pp. 32 - 62 
existência de uma vontade soberana capaz de suspender a ordem e o Direito ${ }^{15}$, ou seja, a existência do soberano como figura essencial do Direito ocidental e da sua ordem política. O soberano existe porque tem o poder de decretar a exceção do direito, ou seja, suspender o direito para decretar a existência da vida nua. Só um poder soberano, que esteja fora da ordem e acima do direito, tem o poder de decretar a suspensão do direito para os outros ${ }^{16}$.

Há, hodiernamente, uma coimplicação originária entre a sacralidade da vida e o poder soberano $^{17}$, e esta confusão vai além da origem religiosa das nossas sociedades (do Direito e da política), que é inquestionável e muito pouco levada em conta nas nossas sociedades secularizadas, em que o nascimento do sujeito e a soberania uniram-se no sujeito soberano ${ }^{18}$, fundamento da Nação-Estado ${ }^{19}$.

Assim, não se trata do homem como sujeito político, mas do seu simples nascimento e exposição ao poder, como condição humana perecível ${ }^{20}$. Manifesta-se então, uma cumplicidade persistente entre a exceção soberana e a vida humana. A vida humana é capturada dentro da ordem na medida em que está presa à figura da exceção. Ou seja, a vida humana existe dentro do Direito sempre com a ameaça potencial de ser decretada vida nua, em razão da condição perecível do humano, da vida do vivente ${ }^{21}$.

E a "vontade soberana", que tem o poder de decretar a exceção, continua sendo constitutiva da ordem moderna, inclusive do Estado de Direito. Trata-se de prerrogativa que coloca a vida humana, ou melhor, todas as vidas humanas, sobre a potencial ameaça da exceção. Logo, se por qualquer circunstância, uma pessoa ou um grupo populacional representar uma ameaça, real ou

\footnotetext{
${ }^{15}$ AGAMBEN, Giorgio. Homo Sacer: o poder soberano e a vida nua I. Belo Horizonte: UFMG, 2002, p. 172.

16 RUIZ, Castor M. M. Bartolomé. A exceção jurídica na biopolítica moderna. Disponível em: http://www.ihuonline.unisinos.br/index.php?option=com_content\&view=article\&id=4044\&secao=371. Acesso em: 18 abril, 2017.

17 A reflexão sobre o "campo" e a figura do "muçulmano" evidencia-nos este equívoco (coimplicação) do pensamento histórico ocidental, que é a tácita confusão entre categorias éticas e jurídicas, ou ainda, de forma mais enfática, entre as categorias de que nos servimos em matéria moral e/ou religiosa, todas contaminadas com o direito: a culpa, a responsabilidade, a pena, a inocência, o julgamento e a absolvição. Direito que alimenta a crueldade, a exclusão. Não é por outra razão a afirmação freudiana de que os meios civilizatórios fortalecem o que é anticivilizatório (Vide GARBELLINI CARNIO Henrique; GUERRA FILHO, Willis Santiago. Teoria política do direito: a expansão política do direito. $2^{\mathrm{a}}$. ed. São Paulo: Revista dos Tribunais, 2013, p. 80 e ss). É pois, nesse contexto, que Agamben propõe um "retorno", se é que saímos dele, aos campos de concentração, sendo o homo sacer, o indivíduo abandonado, expulso da cidade, a quem se podia matar sem cometer delito de homicídio (vide: AGAMBEN, Giorgio. O que resta de Auschwitz: o arquivo e a testemunha (Homo Sacer III). Saõ Paulo: Boitempo, 2008).

${ }^{18}$ AGAMBEN, Giorgio. op. cit., p. 93 e ss.

${ }^{19}$ ANTELO, Raul. Lindes, limites, limiares. v. 1. Boletim de Pesquisa Nelic, 2008, p. 9 apud GARBELLINI CARNIO Henrique; GUERRA FILHO, Willis Santiago, op. cit., p. 75.

${ }^{20}$ AGAMBEN, Giorgio. op. cit., p. 93 e ss.

${ }^{21}$ AGAMBEN, Giorgio. op. cit., p. 93 e ss; ARENDT, Hannah, op. cit. p. 26 e ss. Ou ainda, para Heidegger, a "vida fática", o ser-aí (dasein), o humano enquanto ente destacado, único capaz de questionar o ser (vide: HEIDEGGER, Martin. Ser e tempo. Petrópolis: Vozes, 2006).
} 
suposta, para a ordem, eles poderão sofrer a suspensão parcial ou total dos direitos para melhor controle de suas vidas ${ }^{22}$.

A política da exceção jurídica foi e continua sendo amplamente utilizada pela ciência do Direito para controlar os grupos sociais “perigosos" para a ordem ${ }^{23}$. A questão é: quem tem o poder de decidir quem é perigoso? Por que é perigoso?

Quem tem poder de decidir a periculosidade de uma vida para a ordem é a vontade soberana, já que qualquer um pode ser perigoso para a decisão soberana, por qualquer motivo por ela determinado, todos os seres humanos têm sobre si a possibilidade de que lhes seja decreta a exceção, e como tal reduzidos à condição de homo sacer, sujeitos ao exílio, ao a-bandono, ao des-terro. Eis aí o surgimento da relação (inclusão-exclusão) de indiferença, de banimento, de abandono ${ }^{24}$.

A vida nua (do ser nascido e exposto ao poder: nascimento $\mathrm{X}$ soberania ${ }^{25}$ ) expulsa da ordem pela exceção da vontade soberana está condenada ao banimento. Ela é uma vida banida e, como consequência, uma vida bandida. A consequência da exceção sobre a vida é o banimento. A vida banida da ordem se torna uma vida bandida. O bando, que também é uma figura jurídica do banimento, se transforma socialmente numa vida banida. Os banidos são bandidos porque foram expulsos da ordem e sobre eles se decretou uma exclusão inclusiva que os tornou vida nua ${ }^{26}$.

Nesta senda, vale a lição de Primo Levi, em sua obra “É isto um homem?”, onde apresenta algumas memórias e reflexões do período que passou no campo de concentração, asseverando que condição humana mais miserável do que aquela não existe, não dá para imaginar.

Nada mais é nosso: tiraram-nos as roupas, os sapatos, até os cabelos, se falarmos, não nos escutarão - e, se nos escutarem, não nos compreenderão. Roubaram também o nosso nome, e, se quisermos mantê-lo, devemos encontrar dentro de nós a força para tanto, para que, além do nome, sobre alguma coisa de nós, do que éramos ${ }^{27}$.

E com isso, os seres humanos são privados de tudo, de dignidade e de discernimento - pois quem perde tudo, muitas vezes perde a si mesmo. E "a experiência no campo de extermínio é igual a chegar ao fundo, onde o acordar é regressar do nada". No campo não há criminosos e nem loucos. "Não há criminosos porque não existe uma lei moral a ser violada, e não há loucos porque somos

${ }^{22}$ RUIZ, Castor M. M. Bartolomé. op. cit., p. 14.

${ }^{23}$ Vide: JAKOBS, Günther. Derecho Penal del ciudadano y Derecho Penal del enemigo. Trad. Manuel Cancio Meliá. Madrid: Civitas, 2003.

${ }^{24} \mathrm{O}$ abandonado ou mesmo bandoleiro, é um sujeito muito peculiar e complexo, que não é só excluído da lei, mas alguém orientado para que a lei nele permaneça intacta, ao preço de mantê-lo amarrado, a-bandonando-o, de tal forma que não é possível nunca se saber ao certo se o bandito - desterrado, exilado, refugiado ou o apátrida - está dentro ou fora da lei, já que ele habita no limite da própria vida (GARBELLINI CARNIO Henrique; GUERRA FILHO, Willis Santiago, op. cit., p. 76).

${ }^{25}$ AGAMBEN, Giorgio. op. cit., p. 93 e ss.

${ }^{26}$ RUIZ, Castor M. M. Bartolomé. op. cit., p. 14 e ss.

${ }^{27}$ LEVI, Primo. op. cit., p. 25. 
programados, cada ação nossa é, neste tempo e neste lugar, claramente a única possível (...)”. Para Primo Levi é estranho, de alguma maneira, sempre se tem a impressão de ter sorte. Seja porque não foi escolhido para a câmara de gás, seja porque choveu, mas não ventou ${ }^{28}$.

No campo de concentração, o intestemunhável tem nome, chama-se "muçulmano" (homens-múmia, mortos-vivos) ${ }^{29}$. Na situação extrema do campo, estava em jogo "continuar sendo ou não um ser humano", o muçulmano marcava, de algum modo, o instável umbral em que o homem passava a não ser não-homem, e o diagnóstico clínico passava a ser a análise antropológica ${ }^{30}$.

E o que se chama estado de exceção, para os juristas, é uma situação extrema ou situação limite para filósofos e teólogos. O campo de concentração é exatamente o lugar em que o estado de exceção coincide de maneira perfeita, com a regra, e a situação extrema converte-se no próprio paradigma do cotidiano.

O que está em jogo na "situação extrema" é, portanto, "continuar sendo ou não um ser humano", tornar-se ou não um muçulmano. Tratava-se de conseguir conservar a dignidade e respeito em si - mesmo que, no campo, este e aquela não podiam traduzir-se sempre em ações correspondentes.

O muçulmano é alguém que abriu mão da margem irrenunciável de liberdade e que, consequentemente, extraviou qualquer traço de vida afetiva e humanidade. Em Auschwitz, o Muselman era representado pelo prisioneiro sem esperança e abandonado pelos demais companheiros, uma espécie de cadáver ambulante, oco, um invólucro, um número ${ }^{31}$.

O que significa continuar sendo homem? O sofrimento é levado à potência mais extrema, pois já não se possui, porém, nada de humano. A potência humana confina com o inumano, o homem suporta também o não-homem.

A respeito da degradação da morte no nosso tempo, Foucault, propôs uma explicação em termos políticos, vinculando-a à transformação do poder na idade moderna. Segundo Foucault, o poder é definido essencialmente como direito de vida e de morte ("fazer morrer e deixar viver"). O antigo direito de 'fazer morrer e deixar viver' dá lugar a uma figura inversa, que define a biopolítica moderna e que se expressa na fórmula 'fazer viver e deixar morrer'.

\footnotetext{
${ }^{28}$ Ibidem, p. 133.

${ }^{29}$ A explicação mais provável do termo muçulmano nos remete ao significado literal do termo árabe mulsim, que significa quem se submete incondicionalmente à vontade de Deus. Ser resignado. Ou ainda, em decorrência daqueles que, diante da dura vida no campo de concentração, ficam catatônicos (AGAMBEN, Giorgio, op. cit., p. 49-50).

${ }^{30}$ Fomenta-se, com as atrocidades e tratamentos inumanos dos campos de concentração, um empobrecimento da experiência, que sequer pode ser narrado por quem presencia tamanho horror (Vide: BENJAMIN, W. $O$ capitalismo como religião. Trad. Nelio Schneider. São Paulo: Boitempo, 2009). E este, que fita a Górgona, que vai até o fundo, petrifica-se pelo horror, afoga-se, não volta para contar ou, quando volta, o faz mudo (AGAMBEN, Giorgio, op. cit., p. 52)

${ }^{31}$ Ibidem, p. 63.
} 
No continuum biológico da espécie humana, o aparecimento das raças, a hierarquia das raças, a qualificação de certas raças como boas e de outras como inferiores, tudo isso vai ser uma maneira de fragmentar esse campo biológico de que o poder se incumbiu uma maneira de defasar, no interior da população, uns grupos em relação aos outros.

Cidadãos de ascendência ariana versus cidadãos de ascendência não-ariana. Dessa forma, o não ariano tramuta-se em judeu, o judeu em deportado, o deportado em internado, até, alcançar o limite último. O limite é o muçulmano.

Compreende-se então a função decisiva dos campos no sistema da biopolítica nazista. Eles não são apenas o lugar da morte e do extermínio, mas também, e antes de qualquer outra coisa, o lugar de produção do muçulmano, da última substância biopolítica isolável no continuum biológico ${ }^{32}$. Para, além disso, há somente a câmara de gás.

A polêmica tese sustentada por Agamben é a de que a justificação para a irracionalidade dos campos de concentração nazistas repousaria em uma busca de comprovação da inumanidade dos que para lá foram encaminhados, pelo modo como eram destratados os que não foram de pronto exterminado, contrário a qualquer racionalidade, como a de que se prestaria a atender uma finalidade econômica, ao serem sujeitados a trabalhar para o esforço de guerra ou para empresas.

O tratamento desumano atingiria seu objetivo quando suas vítimas, não mais podendo suportá-lo, psiquicamente, ingressaram em um estado catatônico, sem buscar contato com os demais detentos, falando apenas, quando o faziam, sobre como satisfazer a necessidade de comida, ficando, enfim, indiferentes a tudo e a todos, ao mesmo tempo em que definhavam organicamente até a morte. E a experiência é a de que nos campos de concentração se apresenta uma devastadora ausência de normas, tanto rígida, quanto aleatória.

Primo Levi, imprime a ideia do testemunho e deixa muito claro como há na experiência dos campos de concentração um completo esvaziamento da própria condição humana, melhor dizendo, da dignidade humana. O mulçumano marcava o momento em que o homem passava a ser não homem razão pela qual este ambiente extremo entre vida e a morte, o humano e o inumano tem um forte sentido político, a saber, a de que o muçulmano encarna o significado antropológico do poder absoluto de forma radical ${ }^{33}$. Muçulmano é o que viu Górgona, ou seja, é um petrificado de horror ${ }^{34}$.

\footnotetext{
${ }^{32}$ Nos dias de hoje, a barbárie continua existindo, pois apesar da não visibilidade atual, a própria civilização origina e fortalece progressivamente o que é anti-civilizatório (FREUD. O mal-estar na civilização). E os sobreviventes, são aqueles que vivem além, que "vencem", que "sobre-vivem" para além da vida alheia, seja "por prevaricação, habilidade ou sorte" (AGAMBEN, Giorgio. Os afogados e os sobreviventes, apud GARBELLINI CARNIO Henrique; GUERRA FILHO, Willis Santiago. Teoria política do direito: a expansão política do direito. $2^{\mathrm{a}}$. ed. São Paulo: Revista dos Tribunais, 2013, p. 232-235.

${ }^{33}$ GARBELLINI CARNIO, Henrique; GUERRA FILHO, Willis Santiago. Teoria politica do direito: a expansão política do direito. 2. ed. São Paulo: Revista dos Tribunais, 2013, p. 238.

${ }^{34}$ Ibidem. p. 238-240.
} 
E a vida humana é a vida revestida de sentido, capaz de tornar suportável a consciência que tem os humanos de poder não ter sido a qualquer momento, de poder não mais ser ou ser acometido por uma ameaça ao ser, finito, contingente. E esses sentidos de vida foram adquiridos ao ter a história pessoal inserida em uma história comum a outros, que os antecede e irá, também, os suceder. Relatos, narrativas, rememorações - assim como também as comemorações - se prestam para manter esses vetores de sentido comum, de comum-unidade ${ }^{35}$.

A desumanização é o que ocorre quando não se tem mais esses vínculos. Há de se recordar, assim, a origem violenta de toda proibição, tanto sagrada, como jurídica, que garante a vida em sociedade, sustentada pelo enfrentamento da morte.

O incremento da violência na sociedade 'pós-moderna' não poderá ser contido pelo reforço da proibição jurídica, mas antes por uma consideração das consequências psicológicas e sociais da secularização defendida pela ideologia oficial, onde se verifica uma re-sacralização crescente das relações fora das instituições religiosas, ou seja, em seitas ou tribos.

\section{O NASCIMENTO DA BIOPOLÍTICA E A IMPLICAÇÃO DO DIREITO NAS FORMAS DE VIDA: UM BREVE EXCURSO EM MICHEL FOUCAULT ${ }^{36}$}

Neste perpassar evolutivo - comunidade-civilização-Estado - percebe-se uma consequente interiorização e espiritualização da crueldade, como se não bastasse, com total apoio das categorias jurídicas, tanto de Direito Público (em especial, de Direito Penal), como do Privado ${ }^{37}$. E essa crueldade-desumanização decorre, sobretudo, do exponencial esquecimento do sagrado, da secularização, da substituição da antiga "vida em comunidade" pela "vida em sociedade",

\footnotetext{
${ }^{35}$ Ibidem. p. 242

${ }^{36}$ O presente capítulo centra-se, sobretudo, na obra de Michel Foucault, que nasceu em 1926 e faleceu em 1984. Foucault foi um filósofo francês, historiador das ideias, teórico social, e crítico literário. Suas teorias abordam a relação entre poder e conhecimento e como eles são usados no controle social por meio de instituições sociais. Foucault é conhecido pelas suas críticas às instituições sociais, especialmente à psiquiatria, à medicina, às prisões, e por suas ideias sobre a evolução da história da sexualidade, suas teorias gerais relativas ao poder e à complexa relação entre poder e conhecimento, bem como por estudar a expressão do discurso em relação à história do pensamento ocidental. Têm sido amplamente discutidas a imagem da "morte do homem", anunciada em $A s$ Palavras e Coisas, e a ideia de subjetivação, reativada no interesse próprio de uma forma ainda problemática para a filosofia clássica do sujeito. Sua obra centra-se, sobretudo, na vida e nos diferentes processos de subjetivação (FOUCAULT, Michel. Nascimento da biopolítica: curso dado no Collège de France (1978-1979). São Paulo: Martins Fonstes, 2008).

${ }^{37}$ A força material, poder, é a origem do Direito, e não o contrato. Ele perpassa pela justiça privada, pena, vingança, culpa, sacrifício, castigo, crédito e débito. O nascimento do Direito tem relação com a violência e a associação comunitária (CARNIO, Henrique Garbellini. Notas sobre o pensamento antropológico jurídico de Rudolf von Jhering. In: Alvaro de Azevedo Gonzaga e Antonio Baptista Gonzaga (org.), (Re)pensando o direito: estudos em homenagem ao prof. Cláudio de Cicco. São Paulo: Revista dos Tribunais, p. 125-132).
} 
atomizada, composta de sujeitos individualizados, tidos como autônomos e independentes, sem nada mais a dizer-dar um ao outro, que não seja pautado pela realização de interesses pessoais ${ }^{38}$.

Ademais disso, exsurge um "problema" decorrente da vida em sociedade e da manutenção da vida biológica, qual seja, a necessidade de justificar o poder político governamental. E o "sentido da vida", passa a ser defender a vida de "ameaças" oriundas da concentração populacional (da vida em sociedade), tais como: doenças, catástrofes natuarais, criminalidade, controle de natalidade etc $^{39}$.

Fala-se então, no nascimento da biopolítica ${ }^{40}$, que refere-se à maneira pela qual se tentou, desde o início do século XVIII, racionalizar os problemas propostos à prática governamental, pelos fenômenos próprios a um conjunto de seres vivos constituídos em população ${ }^{41}$.

Assim, num sistema preocupado com o respeito aos sujeitos de direitos e à liberdade de iniciativa, questiona-se: como o fenômeno "população", com todos os seus efeitos e problemas específicos, pode ser levado em conta? Como gerí-los? Como e quanto governar, sem restringir a liberdadedos homens? ${ }^{42}$

E para tratar do assunto, Foucault inicia sua obra apresentando seu método, asseverando que irá analisar a "arte de governar" de modo inverso ao historicismo, baseando-se - depois de conhecer "a" e "sobre" prática de governo - na maneira pensada de governar o melhor possível, sem tomar a história como parâmetro, mas levando em conta a prática do governo em si (“"cosnciência de si”), o estudo da racionalização da prática no exercício da soberania política. Assim, ressalva o autor que não pretende interrogar os universais utilizando como método crítico a história, mas partir da decisão da inexistência os universais para indagar que história se pode fazer ${ }^{43}$.

“A arte de governar deve então estabelecer suas regras e racionalizar suas maneiras de fazer propondo-se como objetivo, de certo modo, fazer o dever-ser do Estado tornar-se ser. O dever-fazer do governo deve se identificar como o dever-ser do Estado" ${ }^{\text {.4 }}$. E esse governar, consiste na

\footnotetext{
${ }^{38}$ GARBELLINI CARNIO Henrique; GUERRA FILHO, Willis Santiago. op. cit., p. 242.

${ }^{39}$ Ibidem, p. 242 e ss.

40 A breve abordagem iniciada refere-se ao curso ministrado por Michel Foucault, nos anos de 1978-1979, no Collège de France (FOUCAULT, Michel. Nascimento da biopolítica: curso dado no Collège de France (19781979). São Paulo: Martins Fonstes, 2008).

${ }^{41}$ FOUCAULT, Michel. op. cit., p. 51.

42 Obra identifica três temas na história duas vezes secular do liberalismo: problema da lei e da ordem (law and order), o problema do Estado em sua oposição à sociedade civil, e por fim, problema da biopolítica e o problema da vida (política da vida). Importa salientar, que Foucault só conseguiu tratar dos dois primeiros pontos na sequência deste curso. Segundo ele, acabou se alongando na análise do liberalismo por considerá-lo condição de inteligibilidade da biopolítica (FOUCAULT, Michel. op. cit., p. 117- 137)

${ }^{43}$ FOUCAULT, Michel. op. cit., p. 4-6.

${ }^{44}$ Ibidem. p. 6. Importa salientar que, sob a ótica da Ciência Política, ou da Teoria Geral do Estado, os elementos do Estado são: território, povo (ou população) e soberania (ou poder). Há ainda autores que acrescentam o elemento finalidade (vide: BASTOS, Celso Ribeiro. Curso de Teoria do Estado e Ciência Política. 3. ed. São Paulo: Saraiva, 1995, p. 12; BONAVIDES, Paulo. Ciência Política. 10. ed. São Paulo: Malheiros, 2000, p. 108; DALLARI, Dalmo de Abreu. Elementos de Teoria Geral do Estado. 2. Ed. São Paulo: Saraiva,1998, p. 38.
} 
colocação em prática, no efetivo exercício da soberania, do poder soberano. Ora, se o poder é do povo, que o "delega" ao Estado, espera-se que este o exerça da melhor maneira possível, buscando sempre o bem comum.

Neste ponto, a lei (o Direito), é a exteriorização da vontade geral, produzida, entretanto, pelo Estado. Por isso, Foucault faz uma análise da lei sob duas vias: a via axiomática revolucionária, em que a lei é a expressão de uma vontade (vontade-lei), e é concebida por esta, portanto, como exteriorização de uma vontade coletiva que manifesta a parte do Direito que os indivíduos aceitaram ceder e a parte que eles querem reservar ${ }^{45}$; já numa via radical utilitarista, a lei será concebida como efeito de uma transação que vai colocar, de um lado, a esfera de intervenção do poder público e, de outro, a esfera de independência dos indivíduos ${ }^{46}$. E é justamente neste momento que se constata a implicação do Direito nas formas de vida ${ }^{47}$, pois a maior ou a menor intervenção do poder público que influi diretamente na esfera de independência dos indivíduos, se manifesta de acordo com a previsão legal, que por sua vez é construída de acordo com o modo de governo adotado.

Assim, ante a necessidade de um governo para "racionalizar" e manter o "equilíbrio", que respeite, todavia, a "esfera de independência" dos governados, nasce o Liberalismo como modelo de governo que garante/respeita a liberdade dos indivíduos, na medida em que a "liberdade" está no cerne da questão prática. Entretanto, há duas noções distintas de liberdade, e que fundamentam dois modelos de governo, quais sejam: o que busca assegurar o efetivo gozo dos direitos humanos e o que pretende garantir a independência dos governados. Esses dois caminhos, que se misturam, para constituir, em Direito, a regulação do poder público, faz emergir duas concepções de lei, duas concepções de liberdade, enfim, é essa ambiguidade que caracteriza o liberalismo europeu dos séculos XIX e $\mathrm{XX}^{48}$.

Ocorre que, não é o "seja livre" que o liberalismo formula. O liberalismo formula simplesmente o seguinte: "vou produzir o necessário para tornar você livre. Vou fazer de tal modo que você tenha a liberdade de ser livre. É a gestão, a organização das condições graças às quais podemos ser livres". Para Foucault, portanto, o liberalismo não é o que aceita a liberdade, é o que se propõe a fabricá-la, a cada instante, suscitá-la e produzi-la ${ }^{49}$.

\footnotetext{
${ }^{45}$ Cabe lembrar a crítica feita por Rousseau ao sistema representativo, quando negava a liberdade do povo inglês (vide: ROUSSEAU, Jean-Jacques. O contrato Social. Trad. Pietro Nasseti. 20. ed. São Paulo: Martin Claret, 2001). ${ }^{46}$ FOUCAULT, Michel. op. cit., p. 57.

${ }^{47}$ Não é por motivo diverso que Foucault assinalou outrora que o objeto de todos esses empreendimentos concernentes à loucura, à doença, à delinquência, à sexualidade (problemas de população) e aquilo que lhes falo agora (governo) é mostrar como o par "série de práticas/regime de verdade" forma um dispositivo de saber-poder que marca efetivamente no real o que não existe e submete-o legitimamente à demarcação do verdadeiro e do falso (vide FOUCAULT, Michel. op. cit., p. 27) (grifou-se).

${ }^{48}$ FOUCAULT, Michel. op. cit., p. 57-58.

${ }^{49}$ Ibidem, p. 87-88.
} 
Sendo assim, espera-se que o liberalismo trará a liberdade e a segurança. É essa a economia de poder, própria do liberalismo. Ele nos insere num mecanismo em que terá, a cada instante, que arbitrar a liberdade e a segurança dos indivíduos em torno da noção de perigo. No fundo, se de um lado o liberalismo é uma arte de governar que manipula fundamentalmente os interesses, ele não pode - e é esse o reverso da medalha -, manipular os interesses sem ser, simultaneamente, gestor dos perigos e dos mecanismos de segurança/liberdade, do jogo segurança/liberdade, que deve garantir que os indivíduos ou a coletividade fiquem o menos possível expostos ao perigo ${ }^{50}$.

Por isso a afirmação de que "o lema do liberalismo é viver perigosamente", e é o estímulo do perigo uma das suas principais implicações. Toda uma educação do perigo, toda uma cultura do perigo, aparece de fato, no século XIX, que é bem diferente daqueles grandes sonhos ou daquelas grandes ameaças do apocalipse, da peste, da morte, da guerra, de que se nutria a imaginação política da idade Média. Produz-se, então a emergência, a invasão dos perigos cotidianos, animados, atualizados, postos em circulação, é essa a política do perigo do século XIX, embrião das campanhas de higiene, de doença, de sexualidade, do medo da degeneração: degeneração da família, da raça, da espécie humana. O incentivo ao medo do perigo é de certo modo a condição, o correlato psicológico e cultural interno do liberalismo. Não há liberalismo sem cultura do perigo ${ }^{51}$.

E o liberalismo, enquanto arte de governar, virá do procedimento de controle, de pressão e de coerção, como uma contrapartida e um contrapeso das liberdades, "fornecendo" a liberdade ${ }^{52}$. Em última análise, o que se pretende é mostrar como o par "série de práticas/regime de verdade" forma um dispositivo de saber-poder, que marca efetivamente no real o que não existe e submete-o legitimamente à demarcação do verdadeiro e do falso, "fornecendo e gerindo a liberdade" em sua exata medida, a exemplo do panoptismo que, para Bentham, "é uma fórmula política geral que caracteriza um tipo de governo" 53 . Ocorre que, o Estado não é, em si, uma fonte autônoma de $\operatorname{poder}^{54}$.

Além da conjunção entre a disciplina e o liberalismo (panoptismo), outra consequência é o surgimento de mecanismos que têm por função produzir, insuflar, ampliar as liberdades, introduzir um "a mais" de liberdade por meio de um "a mais" de controle e intervenção (eis o paradoxo). E aqui, o controle não é apenas o "contrapeso" (como no panoptismo), mas o seu princípio motor, produtor de liberdade de trabalho, de liberdade de consumo, de liberdade política etc. A que preço? Ao preço, precisamente, de toda uma série de intervenções, intervenções artificiais, intervenções voluntaristas, intervenções econômicas diretas de mercado, todas medidas fundamentais do Welfare

\footnotetext{
${ }^{50}$ Ibidem, p. 90.

${ }^{51}$ Ibidem, p. 90-91.

52 Ibidem, p. 90 e ss.

${ }^{53}$ FOUCAULT, Michel. op. cit., p. 27.

${ }^{54}$ Ibidem, p. 106.
} 
State, e que serão, a partir de 1946, caracterizadas como sendo em si mesmas ameaças de um novo despotismo $0^{55}$.

Chega-se então à conclusão de que essa arte liberal de governar passa a ser vítima, por si mesma, de uma "crise de governamentalidade", que decorre de fatores como o aumento do custo econômico do exercício das liberdades e expansão legiferante em relação ao mercado, como um excesso de intervencionismo, de imposições e de coerção. Há, enfim e sobretudo, processos de saturação que fazem que os mecanismos produtores da liberdade (convocados para assegurar e fabricar essa liberdade) produzam na verdade, efeitos destrutivos que prevalecem até mesmo sobre o que produzem. É um equívoco de todos esses dispositivos "liberógenos" que produzem, em verdade, o inverso.

E é essa a crise atual do liberalismo, que através desse conjunto de mecanismos, desde os anos 1925-1930, tentou propor fórmulas econômicas e políticas que garantissem os Estados contra o comunismo, o socialismo, o nacional-socialismo, o fascismo, esses mecanismos garantidores de liberdade (liberógenos), instalados para produzir esse "a mais" de liberdade ou para reagir às ameaças que pesavam sobre essa liberdade, foram todos da ordem da intervenção econômica. Assim, tanto os liberais alemães da Escola de Friburgo (1927), quanto os liberais americanos (ditos libertarianos), da Escola de Chicago, ancoraram-se nesse problema do liberalismo, e com o intuito de evitar esse "a menos" de liberdade, que se acarretaria pela passagem ao socialismo, ao fascismo, ao nacional-socialismo, instalaram-se mecanismos de intervenção econômica ${ }^{56}$.

Daí a indagação: Não são esses mecanismos de intervenção econômica que introduzem subrepticiamente tipos de intervenção? Ou ainda, modos de ação que são, eles próprios, pelo menos tão comprometedores para a liberdade quanto essas formas políticas visíveis e manifestas que se quer evitar? Nota-se, portanto, que essas intervenções keynesianas centralizam o debate em torno da política econômica intervencionista elaborada entre 1930-1960 (imediatamente antes e imediatamente depois da guerra), intervenções essas que levaram a "crise" do liberalismo, e que se manifesta em certo número de reavaliações, reestimações, novos projetos na arte de governar, formulados na Alemanha ${ }^{57}$, antes e depois da guerra, e posteriormente nos Estados Unidos ${ }^{58}$.

\footnotetext{
${ }^{55}$ FOUCAULT, Michel. op. cit., p. 107-108. Foucault menciona, a título de exemplo, a política do Welfare State (implementada por Franklin Rosevelt a partir de 1932, como programa econômico e social nos Estados Unidos) como maneira de garantir e produzir, numa situação perigosa de desemprego, mais liberdade.

${ }^{56}$ FOUCAULT, Michel. op. cit., p. 110-111.

${ }^{57}$ Fala-se em ordoliberalismo, traduzido na necessidade de uma política de sociedade e de um intervencionismo social ao mesmo tempo ativo, múltiplo, vigilante e onipresente. De um lado, a formalização da sociedade com base no modelo da empresa e redefinição da instituição jurídica e das regras de Direito necessárias numa sociedade regulada a partir e em função da economia concorrencial de mercado, ou seja, o problema do Direito (FOUCAULT, Michel. op. cit., p. 222).

58 Trata-se aqui do neoliberalismo, como de ação governamental onde se engloba, primeiramente, a questão do monopólio, além disso, o problema daquilo que os neoliberais chamam de ação econômica conforme, e por fim, o problema da política social (FOUCAULT, Michel, op. cit., p. 184). No neoliberalismo americano, trata-se de fato
} 
A crítica feita em nome do liberalismo econômico insiste no perigo que representaria a inevitável sequencia: intervencionismo econômico, inflação dos aparelhos governamentais, superadministração, burocracia, enrijecimento de todos os mecanismos de poder, ao mesmo tempo que se produziram novas distorções econômicas, indutoras de novas intervenções. Mas o que chamou a atenção no neoliberalismo americano foi um movimento totalmente oposto ao que encontramos na economia social de mercado da Alemanha: enquanto esta considera que a regulação dos preços pelo mercado - único fundamento de uma economia racional - é, de per si, tão frágil que precisa ser sustentatda, arranjada, "ordenada" por uma política interna e vigilante de intervenções sociais (que implicam auxílio aos desempregados, cobertura das necessidades de saúde, política habitacional, etc.), o neoliberalismo americano procura, em vez disso, ampliar a racionalidade do mercado, os esquemas de análise que ela propõe e os critérios de decisão que sugere a campos não exclusivamente econômicos, tais como a família e a natalidade; a delinquência e a política penal ${ }^{59}$.

O problema, para Foucault, é teorizar o Estado deduzindo todo esse conjunto de práticas do que seria a essência do Estado em si mesmo e por si mesmo, sem procurar deduzir, a partir do que é o Estado como uma espécie de universal político e, por extensão, o que pode ter sido o estatuto dos loucos, dos doentes, das crianças, dos delinquentes etc, numa sociedade como a nossa. É preciso renunciar a tal análise, primeiro, simplesmente porque a história não é uma ciência dedutiva, segundo, porque o Estado não tem essência, não é um universal, não é uma fonte autônoma de poder $^{60}$. Dito de outra maneira, o que se deveria verificar, é a maneira como os problemas específicos da vida e da população foram postos no interior de uma tecnologia de governo que, sem ter sempre sido liberal, longe disso, não parou de ser acossada desde o fim do século XVIII pela questão do liberalismo. Daí falar-se em biopolítica enquato política da vida ${ }^{61}$.

O Estado nada mais é que o efeito, o perfil, o recorte móvel de uma perpétua estatização, ou de perpétuas estatizações, de transações incessantes que modificam, que deslocam, que subvertem, que fazem deslizar insidiosamente, pouco importa, as fontes de financiamento, a modalidades de investimento, os centros de decisão, as foras e os tipos de controle, as relações entre as autoridades locais, a autoridade central etc. O Estado não é nada mais que o efeito móvel de um regime de governamentalidades múltiplas ${ }^{62}$.

Resta demonstrado, como já foi dito, que a arte de governar é composta por uma "série de práticas" e um "regime de verdade", que forma um dispositivo de saber-poder que marca

e sempre de generalizar a forma econômica do mercado. Generalizá-la em todo o corpo social, e generalizá-la até mesmo em todo o sistema social que, de ordinário, não passa ou não é sancionado por trocas monetárias (FOUCAULT, Michel. op. cit., p. 112).

${ }^{59}$ FOUCAULT, Michel. op. cit., p. 438-439.

${ }^{60}$ FOUCAULT, Michel. op. cit., p. 115.

${ }^{61}$ Ibidem, p. 439.

${ }^{62}$ Ibidem, p. 116-117. 
efetivamente no real o que não existe e submete-o legitimamente à demarcação do verdadeiro e do falso ${ }^{63}$. Eis o “jogo da legitimação jurídica”, em que o Direito é o instrumento que atesta a política govarnamental, validando as intervenções estatais, a racionalização dos direitos humanos, enfim, a gestão da liberdade seja ela qual for.

O próprio poder não faz mais que designar um termo de relações que tem de ser analisado por inteiro, é o que Foucault propôs chamar de governamentalidade, isto é, a maneira como se conduz a conduta dos homens, não é mais que uma proposta de grade de análise para essas relações de $\operatorname{poder}^{64}$.

E não somente o governo não deve criar obstáculo ao interesse de cada um, mas é impossível que o soberano possa ter sobre o mecanismo econômico um ponto de vista que totalize cada um dos elementos e permita combiná-los artificial ou voluntariamente. A mão invisível que combina espontaneamente o interesse, proíbe, ao mesmo tempo, toda forma de intervenção, melhor ainda, toda forma de olhar sobranceiro que permitisse totalizar o processo econômico ${ }^{65}$.

O liberalismo, em sua consistência moderna, começou quando, precisamente, foi formulada essa incompatibilidade essencial entre, por um lado, a multiplicidade não totalizável dos sujeitos de interesse, dos sujeitos econômicos e, por outro lado, a unidade totalizante do soberano jurídico ${ }^{66}$.

A sociedade civil é um conceito de tecnologia governamental, ou antes, é o correlativo de uma tecnologia de governo cuja medida racional deve indexar-se juridicamente a uma economia entendida como processo de produção e de troca. O homo economicus e a sociedade civil são, portanto dois elementos indissociáveis. O homo economicus é, digamos, o ponto abstrato, ideal e puramente econômico que povoa a realidade densa, plena e complexa da sociedade civil. Ou ainda: a sociedade civil é o conjunto concreto no interior do qual é preciso recolocar esses pontos ideais que são os homens econômicos, para poder administrá-los convenientemente. Logo, ambos fazem parte do mesmo conjunto, o conjunto da tecnologia da governamentalidade liberal ${ }^{67}$.

A sociedade civil é como a loucura, é como a sexualidade. É o que Foucault define como "realidades de transação", ou seja, é precisamente no jogo das relações de poder e do que sem cessar lhes escapa, é daí que nascem, de certo modo, na interface dos governantes e dos governados, essas figuras transacionais e transitórias que, mesmo não tendo existido desde sempre, nem por isso são menos reais e que podemos chamar, neste caso, de sociedade civil, em outros de loucura, etc.

\footnotetext{
${ }^{63}$ FOUCAULT, Michel. op. cit., p. 27.

${ }^{64}$ FOUCAULT, Michel. op. cit., p. 258.

${ }^{65}$ Adam Smith: o interesse comum exige que cada um saiba entender o seu (interesse) e obedecer a ele sem obstáculo. Em outras palavras, o poder, o governo, não pode criar obstáculo ao jogo dos interesses individuais (FOUCAULT, Michel. op. cit., p. 381).

${ }^{66}$ FOUCAULT, Michel. op. cit., p. 384.

${ }^{67}$ Ibidem, p. 402-403.
} 
Sociedade civil, portanto, como elemento de realidade transacional que parece plenamente correlativa dessa forma de tecnologia governamental chamada de liberalismo, isto é, uma tecnologia de governo que tem por objetivo sua própria autolimitação, na medida em que é indexada à especificidade dos processos econômicos ${ }^{68}$. A sociedade civil é uma matriz permanente de poder político. Uns vão dar sua opinião. Outros vão dar ordens. Uns vão refletir, outros vão obedecer. Ela é o motor da história ${ }^{69}$.

Neste passo, indaga-se: o que é a política, finalmente, senão ao mesmo tempo o jogo dessas diferentes artes de governar com seus diferentes indexadores e o debate que essas diferentes artes de governar suscitam? Aí, nasce a política, para Foucault ${ }^{70}$.

E ante o problema do Estado em oposição à sociedade civil, a política governamental, que surge na primeira metado do século XIX, como solução, é o liberalismo, que segundo Foucault, deve ser analisado como "princípio e método de racionalização do exercício do governo racionalização que obedece, e é essa a sua especificidade, à regra interna da economia máxima"”1 .

O liberalismo é atravessado pelo princípio: "sempre se governa demais". E não é ele uma utopia não realizada. Sem dúvida, tanto quanto de uma reflexão jurídica, o liberalismo tampouco deriva de uma análise econômica. Não foi a idéia de uma sociedade política fundada num vínculo contratual que lhe deu origem. Mas na busca de uma tecnologia liberal de governo, veio à luz que a regulação pela forma jurídica constituía um instrumento muito mais eficaz do que a soberania ou a moderação dos governantes ${ }^{72}$.

Daí porque abordar a legitimação pelo Direito das práticas governamentais como um “jogo de legitimação jurídica" que tem, por consequência, e por razões óbvias, "implicações fundamentais nas formas de vida", uma vez que a vida nua do sujeito soberano, daquele que nasce e se expõe ao poder do Estado, se "a-sujeita” à gestão estatal das liberdades ${ }^{73}$. E é isso que o liberalismo se propõe a fazer: gerir as liberdades. Ocorre que, essa gestão coloca o Estado em oposição à sociedade civil e, ao indivíduo, e é a partir desta oposição que o Estado passa a promover a interiorização e espiritualização da crueldade, da indignidade, e como se não bastasse, com apoio das categorias jurídicas $^{74}$.

\footnotetext{
${ }^{68}$ Ibidem, p. 404.

${ }^{69}$ Ibidem, p. 412-414.

${ }^{70}$ FOUCAULT, Michel. op. cit., p. 424.

${ }^{71}$ Ibidem, p. 432.

${ }^{72}$ Ibidem, p. 433-436.

${ }^{73}$ AGAMBEN, Giorgio. op. cit., p. 93 e ss.

${ }^{74}$ GARBELLINI CARNIO, Henrique; GUERRA FILHO, Willis Santiago. op. cit., p. 76.
} 
O excesso de governamentalidade faz surgir o regime de guerra. Na Alemanha, observa-se o nazismo, um tipo de economia dirigista e planifica, oriunda do período de 1914-18 e da mobilização geral dos recursos e dos homens, foi também o socialismo do Estado ${ }^{75}$.

O resultado disso tudo, é a procupação do governo em justificar suas intervenções, em especial para essa "manutenção da vida", sobretudo em seu sentido biológico (zoé), pouco importando se há o efetivo gozo das liberdades (bios), se há vida digna, vida para o sujeito vivenciar, e não apenas "sobre-vida""76.

E é daí, da verificação da condição humana, enquanto zoé e bios (em Aristóteles: politikòn zôon), que Foucault desenvolve a teoria da biopolítica: "por milênios, o homem permaneceu o que era para Aristóteles: um animal vivente e, além disso, capaz de existência política; o homem moderno é um animal em cuja política está em questão a sua vida de ser vivente"77 . Para Aristóteles, o ser humano não ingressa na polis somente para viver, e sim para "a vida boa", para bem viver, e a finalidade última da existência política é a eumeria, o belo dia. A polis, portanto é uma criação racional do ser humano com a única finalidade de proporcionar o bem viver, o bem-estar social. $\mathrm{O}$ "belo dia", porém, jamais se realizou e o motivo do fracasso, segundo Agamben, é a natureza do poder soberano.

Disso decorre que todo governo é capaz de uma ação de tal ordem que inclua um elemento ditatorial em sua constituição, ou seja, a possibilidade de instaurar todos os tipos de violência a serviço do próprio Direito ${ }^{78}$. E então, o poder soberano é aquele que decide pelo Estado de exceção, onde a vida se torna vida nua. "O que a 'arca' do poder contém em seu centro é o estado de exceção - mas este é um espaço essencialmente vazio, onde uma ação humana sem relação com o Direito está diante de uma norma sem relação com a vida"79.

No atual contexto de globalização, isto é, o atual mundo regido por uma única ordem econômica, política, policial e militar, num mundo sem fronteiras, surgem figuras novas que acabam ficando à margem do Direito e da sociedade, reatualizando os campos de concentração da Alemanha Nazista. Existem hoje inúmeros campos de refugiados, "campos de concentração" onde estão suspeitos de terrorismo. Há uma soberania mundial que atua suspendendo uma ordem jurídica

\footnotetext{
${ }^{75}$ FOUCAULT, Michel. op. cit., p. 437.

${ }^{76}$ Em "O poder soberano e a vida nua", Agamben trata da questão da vida nua ou comum (zoé) e da vida política ou politizada (bios). Zoé é a vida natural, regida pelas normas da natureza e dos instintos puramente animais, livre da cultura, da vontade e da liberdade humana. Bios é uma vida baseada na práxis do sujeito e historicamente elaborada (AGAMBEN, Giorgio. O poder soberano e a vida nua. Belo Horizonte: Humanitas, 2010, p. 9). Segundo Aristóteles, por uma qualidade própria, que é a linguagem, o ser humano passa de zoé a politikòn zôon, isto é, animal político, o que lhe possibilita uma vida política (ARISTÓTELES. Política. Lisboa: Vega, 1998, p. $55)$.

77 FOUCAULT, Michel. História da sexualidade I: a vontade de saber. São Paulo: Graal, 2005, p. 134.

${ }^{78}$ AGAMBEN, Giorgio. op. cit., p. 37

${ }^{79}$ AGAMBEN, Giorgio. Estado de exceção. São Paulo: Boitempo, 2011, p. 131.
} 
internacional, criando não sujeitos, extirpados de sua cidadania. O Estado de Exceção se apresenta como a forma legal daquilo que não pode ter forma legal ${ }^{80}$.

E o significado biopolítico do Estado de exceção, é que ele pode "suspender" os direitos dos cidadãos, produzindo um ser inominável e inclassificável, um não sujeito, um inimigo, um bandido, exogrupo ${ }^{81}$, um homo sacer. E tal transformação da vida humana em objeto do poder soberano a reduz à condição de vida puramente biológica, pronta para ser manipulada pelos dispositivos ordenadores do poder (vida nua). Assim, as estruturas do biopoder mostram como a vida nua vai, progressivamente, coincidindo com o atual espaço político, como por exemplo, nas políticas de castração dos direitos humanos, em que os sujeitos são jogados em situação de nãosujeitos, em zonas de anomia ${ }^{82}$.

\section{SOBRE DIREITOS HUMANOS NA ERA DA BIOPOLÍTICA: OS LIMITES AO JOGO DA LEGITIMAÇÃO JURÍDICA ${ }^{83}$}

Não se pode olvidar da existência de um Direito Natural, que é objeto de profunda reflexão desde a Antiguidade clássica, e que, a partir do século XVII, se materializa no desenvolvimento da teoria jusnaturalista dos direitos do homem, cujo fundamento reside justamente na natureza humana, racional e afetiva, de modo que os deveres impostos pelas "leis não escritas" assumiram, a partir de então, a forma histórica dos direitos humanos ${ }^{84}$.

Eis a existência, desde os primórdios de nossa civilização, da aguda consciência de leis não escritas, iniludíveis, das quais não se pode dizer quando nem onde surgiram, mas que são cogentes como princípios objetivos, transcendendo fronteiras e limitações tanto espaciais quanto temporais e cuja interpretação ensejou a positivação nas modernas constituições dos Estados democráticos em nosso constitucionalismo moderno ${ }^{85}$.

No século XVIII, com a superação do ancièn règim e o desencadeamento do período da Ilustração, a Declaração de Direitos da Virgínia de 1776, que em seu art. 3. ${ }^{\circ}$ assinalou:

\footnotetext{
${ }^{80}$ JUNGES, Fábio César; RIGO, José Rogério. Biopolítica: reflexões a partir de Giorgio Agamben. (in) Anais do Congresso Internacional das Faculdades EST. São Leopoldo: EST, v. 1, 2012, p.1154-1161. Disponível em: file:///C:/Users/gerso/Downloads/28-770-1-PB.pdf. Acesso em 20 abril. 2017.

${ }^{81}$ GIL GIL, Alicia. La expansión de los delitos de terrorismo en España a través de la reinterpretación jurisprudencial del concepto “Organización Terrorista”. ADPCP, vol. LXVII, 2014.

${ }^{82}$ AGAMBEN, Giorgio. op. cit., p. 116-118.

83 Oswaldo Giacoia Junior, nascido em 1954, é um filósofo e professor universitário brasileiro do Paraná, estudioso de Nietzsche, bem como do idealismo alemão e de seus desdobramentos contemporâneos diversos, dos quais o pensamento de Michel Foucault, Hans Kelsen, Carl Schmitt, Giorgio Agamben etc.

${ }^{84}$ GIACOIA JUNIOR, Oswaldo. "Aula inaugural. Sobre direitos humanos na era da bio-política”. In: KRITERION. Belo Horizonte, n. 118. Dez/2008, pp. 267-268. Giacoia recorre à Antígona por ser ela um documento legítimo e fundador da fonte das leis não escritas, porque ínsitas à natureza do ser humano, ainda que contrariadas pelo direito positivo.

${ }^{85}$ GIACOIA JUNIOR, Oswaldo. op. cit., p. 269.
} 
O governo é, ou deverá ser, instituído para o benefício comum, a proteção do povo, da nação, ou da comunidade; de todas as várias formas e modos de governo a melhor é aquela que é capaz de produzir o maior grau de felicidade e segurança, e que se encontra mais efetivamente garantida contra o perigo da máadministração; e que onde quer que qualquer governo seja considerado inadequado ou contrário a esses propósitos, a maioria da comunidade tem um indubitável, inalienável, e irrevogável direito de o reformar, alterar, ou abolir, do modo que seja considerado melhor conducente ao bem-estar público. (grifou-se)

Na mesma linha, a Declaração dos Direitos do Homem e do Cidadão, de 1789, que, diretamente emanada da mesma atmosfera espiritual que conduziu à Revolução Francesa e ao republicanismo contemporâneo, dispõe que "objetivo de qualquer associação política é a conservação dos direitos naturais e imprescritíveis do homem. Esses direitos são a liberdade, a propriedade, a segurança e a resistência à opressão." (grifou-se)

Esse mesmo diapasão é ratificado pelo documento que constitui talvez a expressão mais radical do entendimento moderno de política e soberania: a Declaração dos Direitos do Homem e do Cidadão da Constituição Francesa de 24 de junho de 1793, cujos artigos primeiro e segundo dispõem: "O objetivo da sociedade é a felicidade comum. $\underline{\mathrm{O} \text { governo é instituído para garantir ao }}$ homem o usufruto dos seus direitos naturais e imprescritíveis. Esses direitos são a igualdade, a liberdade, a segurança, a propriedade". (grifou-se)

Percebe-se, pois, que, “desde o surgimento do moderno Estado Democrático de Direito, “o fundamento e a justificação teórica da autoridade política não se encontram mais na vontade de Deus, nos costumes herdados pela tradição, nem mesmo na história, mas solidamente plantados na natureza humana”. Dela brotam direitos fundamentais e inalienáveis, direitos legitimamente atribuíveis a todo homem em função de sua humanidade, prerrogativas éticas e jurídicas universais, cuja validade se sobrepõe aos ordenamentos jurídico-políticos empíricos, que, com efeito, teriam a função precípua justamente de assegurá-los e torná-los efetivos ${ }^{86}$.

Tendo em vista a incansável busca por um Estado ideal, promotor de significativas alterações no seio social, pode-se falar, cronologicamente, em três gerações representativas desse processo evolutivo dos direitos do homem. Que correspondem, paralelamente, a um processo evolutivo na composição estrutural do Estado de Direito ${ }^{87}$. Assim, no Estado Liberal de Direito, são principalmente garantidos os direitos civis e políticos, onde residem as liberdades individuais (direitos fundamentais de primeira dimensão), alcançados com o intuito de libertar os indivíduos do

\footnotetext{
${ }^{86}$ Ibidem, p. 269-270.

${ }^{87}$ BOBBIO, Norberto. A era dos direitos. Trad. Carlos Nelson Coutinho. 9. ed. Rio de Janeiro: Campus, 1992, p. 4-10.
} 
absolutismo estatal $^{88}$, cuja titularidade centra-se na pessoa moral ${ }^{89}$. Nesse passo, exige-se do ente dominante uma prestação negativa, uma abstenção estatal em respeito ao surgimento dos direitos civis e políticos dos cidadãos ${ }^{90}$.

Revolução Francesa e a consequente criação do Estado moderno, alimenta-se, com as ideias iluministas, os ideais de liberdade, cunhados inicialmente nos aspectos econômicos - consagrados na expressão laissez-faire, laissez-passer - irradiam seus efeitos para outras dimensões da vida humana $^{91}$, quando se passa a renunciar ao absolutismo em favor da liberdade. Após a construção liberal, novas necessidades brotaram no seio social, dando ensejo à busca por uma igualdade, não à meramente formal, mas a substancial, capaz de mitigar as discrepâncias resultantes do liberalismo do Estado de distância, nascendo então a concepção de Estado social de Direito, onde objetiva-se resguardar, também, os direitos sociais, culturais e econômicos, uma vez que a desigualdade social que resultou do movimento libertador passou a desconfortar a harmonia e a paz social ${ }^{92}$, e o homem seria sido como "lobo" dos seus pares, como o grande vilão perante os demais membros da sociedade, também em decorrência da competitividade que ascendeu com a nova concepção de "mercado"

Emerge então, um modelo de Estado Intervencionista, o "Estado providência", prestacionista, que atende aos anseios sociais e reduz as desigualdades com mecanismos compensatórios, positivos, com um facere. A adjetivação pelo social pretende a correção do individualismo liberal por intermédio de garantias coletivas, "marcando a passagem do plano abstrato do destinatário genérico - "o homem", o gênero humano - para categorias concretas ou grupos sociais específicos (trabalhador, idoso, mulher, criança, adolescente, deficiente, consumidor, etc.) "94. Corrige-se o liberalismo clássico pela reunião do capitalismo com a busca do bem-estar

\footnotetext{
${ }^{88}$ BONAVIDES, Paulo. Curso de Direito Constitucional. 20. Ed. São Paulo: Malheiros, 2007, p. 563-564, leciona que os direitos de primeira geração ou direitos de liberdade têm por titular o indivíduo, são oponíveis ao Estado, traduzem-se como faculdades ou atributos da pessoa e ostentam uma subjetividade que é seu traço mais característico; enfim, são direitos de resistência ou de oposição perante o estado. São, por igual, direitos que valorizam primeiro o homem-singular, o homem das liberdades abstratas, o homem da sociedade mecanicista que compõem a chamada sociedade civil, da linguagem jurídica mais usual.

${ }^{89}$ GIACOIA JUNIOR, Oswaldo. op. cit., p. 270.

${ }^{90} \mathrm{O}$ anseio pela liberdade face ao intervencionismo do "Estado" monarca restou demonstrado já em 1215, quando da conquista da Magna Carta, pelos ingleses junto ao Rei João Sem Terra, momento em que desejavam que lhes fosse permitido construir livremente suas vidas, legalizando e limitando o totalitarismo do Leviatã (Cf. HOBBES, Thomas. Leviatã. São Paulo: Abril Cultural, 1974; LOCKE, John. Dois tratados sobre o governo. São Paulo: Martins Fontes, 1998).

${ }^{91}$ Cf. ROUSSEAU, Jean-Jacques: O contrato social (Título original: Le Contrat Social revisado por Antonio Carlos Marquês). Trad. Pietro Nasseti. 20. ed. São Paulo: Martin Claret, 2001.

92 BOBBIO, Norberto. A era dos direitos. Trad. Carlos Nelson Coutinho. 9. ed. Rio de Janeiro: Campus, 1992, p. 4-7.

${ }^{93}$ Cf. SMITH, Adam. Inquérito sobre a natureza e as causas da riqueza das nações. Trad. de Armandina Henriques Puga e Marilia Alves Pereira. Lisboa: Fundação Calouste Gulbenkian, 2006, v. 1.

${ }^{94}$ GIACOIA JUNIOR, Oswaldo. op. cit., p. 271.
} 
social, fórmula geradora do welfare state no pós-Segunda Guerra Mundial, projetando-se um modelo onde o bem-estar e o desenvolvimento social pautam as ações do ente público ${ }^{95}$.

Numa terceira geração, surgem os direitos coletivos, de solidariedade ou de titularidade difusa, sendo também o momento histórico em que predomina a tendência à internacionalização dos direitos humanos. Ocorre, então, a positivação, tanto no plano das constituições dos Estados nacionais, quanto principalmente naquele do direito internacional público, da proteção aos direitos que concernem solidariamente à humanidade ${ }^{96}$. Trata-se, pois de uma evolução do Estado Social segue em busca ds constitucionalização dos direitos do homem, no sentido de se adotar como núcleo axiológico-legal de todo o Direito ${ }^{97}$. Fala-se então, em nível normativo, em um Estado constitucional de Direito, em que se manifestam os direitos fundamentais de terceira dimensão, tais como a qualidade de vida, o meio ambiente, a liberdade de informática, a biotecnologia, a paz, a assistência e a organização familiar, entre outros metaindividuais ${ }^{98}$, todos "ameaçados pelas consequências indesejáveis do extraordinário progresso e da extensão planetária da tecno-ciência, sobre cuja dinâmica se assenta a configuração atual da sociedade, tanto no âmbito da produção e circulação de bens, como naquele do consumo e lazer" $" 99$.

Almeja-se, outrossim, contrabalancear os excessos de permissividade do liberalismo face ao totalitarismo interventivo do Estado Social, dando ensejo aos direitos de solidariedade, de fraternidade, resultando-se, desta forma, no Estado Constitucional de Direito, ou ainda, mais precisamente, Estado Social e Democrático de Direito, que representa uma concepção sintética fruto da união dos princípios próprios do Estado Liberal e do Estado Social, pressupondo uma superação dos componentes básicos de ambos, enquanto isoladamente considerados, o que permite acrescentar a terceira característica da forma constitucional: a democracia ${ }^{100}$.

\footnotetext{
${ }^{95}$ GARCÍA PELAYO, Manuel. Las transformaciones del Estado Contemporáneo. Madrid: Alianza Universidad, 1982, p. 56.

${ }^{96}$ GIACOIA JUNIOR, Oswaldo. op. cit., p. 271.

97 Assim, elabora-se ordenamento jurídico como um sistema escalonado de normas, cabendo às normas constitucionais (superiores) nortear e inspirar todo o arcabouço jurídico, demonstrando-se o princípio da supremacia imanente da Constituição - a qual embasa todas as leis elaboradas sob a sua égide -, princípio este que objetiva garantir a liberdade humana contra os abusos do poder estatal (KELSEN, Hans. Teoria Pura do Direito. Trad. de João Baptista Machado. 6. ed. Coimbra: Arménio Amado, 1984, p. 374-376). Nesse passo, a República há de ser uma organização política que serve o homem, não é o homem que serve os aparelhos políticoorganizatórios (CANOTILHO. José Joaquim Gomes. Direito Constitucional. 7. ed. Coimbra: Almedina, 2003, p. 225).

${ }^{98}$ PÉREZ LUÑO, Antonio Enrique. La tercera generación de derechos humanos. Madrid: Tecnos, 1990, p. 7577.

${ }^{99}$ GIACOIA JUNIOR, Oswaldo. op. cit., p. 272.

${ }^{100}$ MIR PUIG, Santiago. El Derecho Penal en el Estado Social y Democrático de Derecho. Barcelona: Ariel, 1994, p. 31. O Estado democrático de Direito é, pois, um Estado constitucionalmente conformado e por isso, pressupõe a existência de uma Constituição e a afirmação inequívoca do princípio da constitucionalidade. E é na Constituição - ordenação normativa fundamental e suprema - que o primado do Direito do Estado democrático de Direito encontra sua primeira e decisiva expressão. Constituição essa que garante a efetivação dos direitos e liberdades fundamentais do homem, na sua complexa qualidade de pessoa, cidadão e trabalhador. Nesse sentido, o Estado de Direito é um Estado de distância, pois os direitos fundamentais asseguram ao homem uma autonomia perante os
} vol.12, nº. 22, Rio de Janeiro, 2019.pp.32 - 62 
Destaca-se, a partir da presente análise, uma tendência progressiva de implementação dos direitos humanos através de uma internacionalização progressiva de tutela jurisdicional, que perpassa, inicialmente, pela ótica da titularidade subjetiva destes, partindo de uma especificação inicial abstrata, do "homem" como "cidadão" (1. a geração), passando pelos sociais conferidos a determinadas categorias - por determinações ligadas aos gêneros (diferença entre homem e mulher), às etapas da vida (idosos, crianças, adolescentes), a estados e condições da vida humana (doentes mentais, deficientes físicos) (2. ${ }^{a}$ geração), para de novo retornar, na forma dos direitos de solidariedade, a uma titularidade universal, que subtrai a condição de "cidadão" para ser sujeito de direitos $^{101}$ (direito ao desenvolvimento, ao meio ambiente não poluído, ao patrimônio genético da humanidade) $\left(3 .^{a} \text { geração }\right)^{102}$.

\section{CONCLUSÃO}

Nos dias atuais, a demanda social de proteção dos bens jurídicos não se vê satisfeita de um modo funcional, mostra-se inevitável a expansão do ordenamento com intuito de se alcançar as novas modalidades de violação à personalidade humana, assegurando o livre desenvolvimento desta e da dignidade do homem, a fim de proporcionar-lhe o livre exercício do direito à vida. Diante disso, os direitos fundamentais, como núcleo essencial a todo ser humano, servem de base jurídicopositiva para uma vida e existência digna, exigindo-se a presença de um mínimo existencial.

Faz-se, portanto, imperioso repensar a multiplicidade empregada no tratamento entre o homem e o cidadão, uma vez que os Estados nacionais não podem limitar os direitos do homem à sua esfera de poder discricionário (soberania) e autocrático. A real efetivação dos direitos humanos deve superar a "necessidade" de uma fundamentação e receber, isso sim, uma tutela internacional,

poderes públicos; de outra banda, o Estado de Direito é um Estado antropologicamente amigo, ao respeitar a dignidade da pessoa humana e ao empenhar-se na defesa e garantia da liberdade, da justiça e da solidariedade (CANOTILHO, José Joaquim Gomes; MOREIRA, Vital. Fundamentos da Constituição. Coimbra: Coimbra, 1991, p. 83).

101 Importa lembrar aqui, a análise crítica de Giorgio Agamben, asseverando que o simples nascimento e a exposição ao poder do Estado (vida nua) uniram-se no "sujeito soberano", fundamento do Estado moderno. Não é o homem como sujeito político, livre e consciente, mas do indivíduo que nasce e se a-sujeita ao Estado de Direito, que a partir de então irá "fornecer-lhe" a liberdade e os demais direitos inerentes à condição de cidadão/sujeito soberando (vide: AGAMBEN, Giorgio. O que resta de Auschwitz: o arquivo e a testemunha (Homo Sacer III). São Paulo: Boitempo, 2008).

${ }^{102}$ A realidade efetiva dessa tendência pode ser comprovada pelos tratados e convenções decorrentes da Declaração Universal dos Direitos do Homem e do Cidadão e da Carta das Nações Unidas de 1948. Assim, por exemplo: pela Convenção para a Prevenção e Repressão do Crime de Genocídio (1948), pelo Estatuto dos Refugiados (1951), pelo Estatuto dos Apátridas (1954), pela Convenção para a Eliminação de Todas as Formas de Discriminação (1965), e, mais recentemente, pela Convenção Européia dos Direitos Humanos, pelo Pacto de São José para a América Latina, e pela atuação efetiva do Tribunal Penal Internacional (GIACOIA JUNIOR, Oswaldo, op. cit., p. 272). 
perpassando por uma cidadania fundada no Direito Internacional Público, solidificando o essencial e indispensável respeito universal à dignidade da pessoa humana ${ }^{103}$.

Para Marx, essa oposição "homem 'E' cidadão" presentes nos textos das declarações de direito das constituições francesa e norte-americana decorrem da pretensão burguesa à emancipação que encerra uma contradição que se expressa, em termos políticos, entre os direitos do homem (considerado em seu estado natural de indivíduo privado e egoísta) e de cidadão (agora considerado do ponto de vista de sua pertença a uma comunidade política baseada no reconhecimento de direitos civis). Contudo, a esfera do Estado não é mais do que a instância de organização jurídico-política, que assegura e perpetua a diferença e a dominação de classes, a exploração e os interesses econômicos da burguesia, detentora do poder político. Nessas condições, os direitos do homem, contrapostos aos do cidadão, fariam parte do dispositivo jurídico que, ao mesmo tempo, legitima e acoberta as relações de dominação sob a capa da igualdade formal de todos perante a lei universal ${ }^{104}$.

As previsões de Marx foram precisas, de modo que, já no início do século XX, o mundo, em especial, a Europa, vivenciou os lastimáveis acontecimentos que deram ensejo à multiplicação das minorias, de etnias diversas que foram sendo submetidas a regramentos especiais (ONU) em decorrência do crescente processo de desintegração nacional. E diante da incapacidade dos Estados nacionais "proteger" os indivíduos sem cidadania, restou evidente o hiato entre o homem e o cidadão, já que a cidadania seria uma conditio sine qua non da tutela estatal, e por consequência, da fruição e gozo de direitos ${ }^{105}$. Daí o questionamento acerca da condição humana não ser suficiente, bem como a proposta de uma releitura da Antígona.

Nesse passo, para Hannah Arendt, a concepção jusnaturalista dos direitos humanos, que teria como única condição-fundamento a humnitas, é ineficaz, na medida que, conforme

${ }^{103}$ BOBBIO, Norberto, Op. cit., 71. É essa a lição de Oswaldo Giacoia, que fazendo alusão ao pensamento de Hannah Arendt e Norberto Bobbio, assinala que "a cidadania deveria ser entendida num sentido ampliado, cujo efetivo exercício restauraria a dignidade da política, entendida como atuação conjunta num espaço para asseguramento do direito a um mundo compartilhado - numa inegável evocação do direito cosmopolita de Kant" (GIACOIA JUNIOR, Oswaldo, op. cit., p. 273-274).

${ }^{104}$ MARX, Karl. A Questão Judaica. 2. Ed. São Paulo: Moraes, 1991, p. 50, apud GIACOIA JUNIOR, op. cit., p. 276-277.

105 Saliente-se que, a essas minorias, o século XX somaram-se os apátridas - aqueles grupos humanos que não dispunham de nenhum estado nacional próprio, em razão da perda da cidadania original, decorrente de alguma revolução ou transtorno político: fenômeno de grandes proporções ocorrido na Europa nos anos que precederam a segunda guerra mundial, agravado pela massiva desnacionalização de judeus alemães, ciganos e armênios, pelas autoridades nazistas, num regime de exceção que, como exceção, durou mais de uma década. Esse fenômeno fez surgir o que Hannah Arendt denominou displaced persons. Pessoas desnacionalizadas e permanentemente deslocadas demonstravam o paradoxo até então oculto na concepção de direitos humanos que remete à Antígona - direitos radicados na natureza do homem, dedutíveis por operação da simples razão, precedentes e alheios à institucionalização política. Esses direitos, tal como os concebiam os jusnaturalistas clássicos, como Hobbes, Rousseau, Grotius e Locke, entre outros, estavam antropocentricamente ancorados na natureza do homem, podendo ser embasados em argumentos cogentes, universalmente válidos e irrecusáveis para qualquer ser de razão (ARENDT, Hannah. O Declínio do Estado Nação e o Fim dos Direitos do Homem. In: Origens do Totalitarismo - Anti-Semitismo, Imperialismo e Totalitarismo. Trad. Roberto Raposo. São Paulo: Companhia das Letras, 1989, p. 327, apud GIACOIA JUNIOR, op. cit., p. 278-279). 
demonstrado, os direitos humanos pressupõem a cidadania política como um fato fundamental, como um verdadeiro pressuposto de efetividade dos direitos do homem ${ }^{106}$.

Para o autor Agamben, o princípio de toda soberania reside na nação, e este vínculo naçãosoberania legitima a autoridade política, numa transição que se estabelece pela mediação nascimento/nacionalidade. Os princípios da natividade e da soberania unem-se no Estado-nação, cujo fundamento é o "homem" (sujeito político livre e consciente), que nasce (vida nua) e é investido como tal pelo princípio da soberania. E a este homem-fundamento do Estado-nação são atribuídos direitos, logo ele é cidadão. Por isso dizer que as declarações de direitos devem ser entendidas como instrumento de re-significação da vida no Estado-nação (de vida nua para a vida do sujeito soberano, como investimento jurídico político da vida no arcabouço institucional do Estado) $)^{107}$.

Agamben continua seu pensamento, onde, seria necessário reler a teoria contratualista como o fundamento da legitimidade do poder político. Em verdade, o relacionamento jurídico-político originário é o bando, que mantém unidos justamente a vida nua e o poder soberano ${ }^{108}$. O bando é essencialmente o poder de remeter algo a si mesmo. E o que foi posto em bando é remetido à própria separação e, juntamente, entregue à mercê de quem o abandona, ao mesmo tempo excluso e incluso, dispensado e, simultaneamente, capturado. Nesse passo, ressalta Agamben que as declarações de direitos integram o dispositivo de abandono, realizando a inclusão da vida nos cálculos e estratégias do moderno poder soberano, de sua gestão e aproveitamento econômico nos quadros da racionalidade instrumental capitalista ${ }^{109}$.

E essa racionalidade, enquanto bio-poder, inclui a vida biológica, tanto ao nível individual dos corpos adestrados, quanto ao nível genérico das populações, que devem ser calculados em termos previdenciários e de assistência social. Por aí dizer que, com a bio-política, a antiga soberania do monarca (poder de fazer morrer e deixar viver) se converte num poder de fazer viver e deixar morrer ${ }^{110}$. Não se trata de contrapor, de modo ingênuo, o direito de soberania contra o biodireito das disciplinas e da regulamentação previdenciária. Trata-se antes de superar essa

\footnotetext{
${ }^{106}$ GIACOIA JUNIOR, Oswaldo. op. cit., p. 279-280.

107 AGAMBEN, Giorgio. Homo Sacer: o poder soberano e a vida nua I. Belo Horizonte: UFMG, 2002, p. 1134135, apud GIACOIA JUNIOR, op. cit., p. 281-282.

${ }^{108}$ Bando é a tradução portuguesa do termo alemão Bann, que significa o poder de governo, a soberania, o direito de estatuir comandos e proibições, de impor e executar penas; também o direito de banir (GIACOIA JUNIOR, op. cit., p. 283).

${ }^{109}$ AGAMBEN, Giorgio. Homo Sacer: o poder soberano e a vida nua I. Belo Horizonte: UFMG, 2002, p. 1134135, apud GIACOIA JUNIOR, Oswaldo. op. cit., p. 284.

${ }^{110}$ Para Foucault, há um racismo no exercício de um poder, e que é, assim, a condição para que se possa exercer o direito de matar. E por tirar a vida não entendo simplesmente o assassinato direto, mas também tudo o que pode ser assassínio indireto: o fato de expor à morte, de multiplicar para alguns o risco de morte ou, pura e simplesmente, a morte política, a expulsão, a rejeição, etc. (FOUCAULT, Michel. Em Defesa da Sociedade. Curso no Collège de France (1975-1976). Trad. Maria Ermantina Galvão. São Paulo: Martins Fontes, 1999, p. 306, apud GIACOIA JUNIOR, op. cit., p. 285).
} 
oposição pelo reconhecimento da função bio-política do próprio direito de soberania (formal, liberal e burguês) ${ }^{111}$.

Daí a falar-se em um "novo Direito", não contaminado pelo princípio da soberania, ao mesmo tempo antidisciplinar e não previdenciário - um Direito não estatal, amparado numa insólita cidadania internacional fundada nos abusos do poder na condição infeliz das vítimas desse abuso, quaisquer que sejam ${ }^{112}$.

Ademais disso, para uma crítica atual dos direitos humanos, seria indispensável levar em conta a figura mais dramática e vulnerável assumida hoje pelo homo sacer: o refugiado, no qual reconhecemos o bandido de nossos tempos. O incluído por exclusão, dispensado e capturado. E é justamente sobre ele que recai a excepcionalidade da resposta estatal, pois ele é excluído e para ele há um tratamento excepcional, um não Direito. Daí a crítica de Agamben, ao asseverar que o Direito não pode tolerar a violência fora do Direito (a exceção), pois se assim o for, a conduta que se pretende evitar, prevenir e punir, estará sendo reproduzida pelo Estado na situação da excepcionalidade $^{113}$. Não se quer aqui que o Direito e a força sejam compreendidos como absolutamente antagônicos, mas que a força seja organizada pelo Direito. Por conseguinte, pode-se dizer que o Direito faz do uso da força um monopólio da comunidade. E, precisamente por fazê-lo, o Direito pacifica a comunidade ${ }^{114}$.

\section{THE STATE OF EXCEPTION IN THE AGE OF BIOPOLITICS: THE GAME OF LEGITIMATION BY LAW}

Abstract: The present work proposes a reflection on the role played by the Rule of Law in the lives of citizens, especially when this state uses liberalism as the art of governing and becomes the manager of human "happiness." For that, a brief study is made in the books of Giorgio Agamben and Michel Foucault, analyzing the concepts of State of exception and biopolitics, respectively developed by them. It returns to the form of exclusion suffered by homo sacer, as Agamben teaches us, comparing it with the "bandit" of our day, also excluded from society more often than not. Finally, the function of Law, used as an instrument to legitimize cruelty and interests that do not conform to the general will. For this, the logical-deductive and inductive-argumentative methods, through fundamental and qualitative analysis, having as resources national and foreign bibliographies.

Keywords: State. Law. Biopolitics. Homo Sacer. State of Exception.

\footnotetext{
${ }^{111}$ GIACOIA JUNIOR, Oswaldo. op. cit., p. 285 e ss.

112 GIACOIA JUNIOR, Oswaldo. op. cit., p. 287-288.

${ }^{113}$ GIACOIA JUNIOR, Oswaldo. op. cit., p. 290-291.

${ }^{114}$ KELSEN, Hans. Teoria Geral do Direito e do Estado. Trad. Luis Carlos Borges. São Paulo: Martins Fontes, 2005, p. 29 apud GIACOIA JUNIOR, Oswaldo. op. cit., p. 291.
} 


\section{REFERÊNCIAS BIBLIOGRÁFICAS}

AGAMBEN, Giorgio, Homo Sacer I: poder soberano e vida nua. São Paulo: Boitempo, 2008.

. O que resta de Auschwitz: o arquivo e a testemunha (Homo Sacer III). São Paulo: Boitempo, 2008.

ANTELO, Raul. Lindes, limites, limiares. v. 1. Boletim de Pesquisa Nelic, 2008.

ARENDT, Hannah. A condição humana. Trad. Roberto Raposo. 11 ed. Rio de Janeiro: GENForense Universitária, 2010.

. O Declínio do Estado Nação e o Fim dos Direitos do Homem. In: Origens do Totalitarismo - Anti-Semitismo, Imperialismo e Totalitarismo. Trad. Roberto Raposo. São Paulo: Companhia das Letras, 1989.

ARISTÓTELES. Política. Lisboa: Vega, 1998.

BAStOS, Celso Ribeiro. Curso de Teoria do Estado e Ciência Política. 3. ed. São Paulo: Saraiva, 1995.

BECCARIA, Cesare. Dos delitos e das penas, Trad. Vicente Sabino Júnior. São Paulo: Editora Pilares, 2013.

BENJAMIN, W. O capitalismo como religião. Trad. Nelio Schneider. São Paulo: Boitempo, 2009.

BOBBIO, Norberto. A era dos direitos. Trad. Carlos Nelson Coutinho. 9. ed. Rio de Janeiro: Campus, 1992.

BONAVIDES, Paulo. Ciência Política. 10. ed. São Paulo: Malheiros, 2000.

CAnotilho, J. J. Gomes. Direito Constitucional e Teoria da Constituição. 3. ed. Coimbra: Almedina, 1998. 
CATTANEO, Mario Alessandro. Pena, diritto e dignità umana: saggio sulla filosofia del diritto penale, Torino, 1990.

DALLARI, Dalmo de Abreu. Elementos de Teoria Geral do Estado. 2. Ed. São Paulo: Saraiva,1998.

FOUCAULT, Michel. Em Defesa da Sociedade. Curso no Collège de France (1975-1976). Trad. Maria Ermantina Galvão. São Paulo: Martins Fontes, 1999

. História da sexualidade I: a vontade de saber. São Paulo: Graal, 2005.

. Nascimento da biopolitica: curso dado no Collège de France (1978-1979). São Paulo: Martins Fontes, 2008.

FREUD, Sigmund. O mal-estar na civilização. São Paulo: Penguin e Companhia das Letras, 1998.

GARBELLINI CARNIO, Henrique. Notas sobre o pensamento antropológico jurídico de Rudolf von Jhering. In: Alvaro de Azevedo Gonzaga e Antonio Baptista Gonzaga (org.), (Re)pensando o direito: estudos em homenagem ao prof. Cláudio de Cicco. São Paulo: Revista dos Tribunais, p. 125-132).

. GUERRA FILHO, Willis Santiago. Teoria política do direito: a expansão política do direito. $2^{\mathrm{a}}$. ed. São Paulo: Revista dos Tribunais, 2013.

GARCÍA PELAYO, Manuel. Las transformaciones del Estado Contemporáneo. Madrid: Alianza Universidad, 1982.

GIACOIA JUNIOR, Oswaldo. "Aula inaugural. Sobre direitos humanos na era da bio-política". In: KRITERION. Belo Horizonte, n. 118. Dez/2008.

GIL GIL, Alicia. La expansión de los delitos de terrorismo en España a través de la reinterpretación jurisprudencial del concepto "Organización Terrorista”. ADPCP, vol. LXVII, 2014. 
HABERMAS, Jürgen. O Futuro da Natureza Humana. Trad. Karina Jannini. São Paulo: Martins Fontes, 2004.

HEIDEGGER, Martin. Ser e tempo. Petrópolis: Vozes, 2006.

HOBBES, Thomas. Leviatã. São Paulo: Abril Cultural, 1974.

JAKOBS, Günther. Derecho Penal del ciudadano y Derecho Penal del enemigo. Trad. Manuel Cancio Meliá. Madrid: Civitas, 2003.

JUNGES, Fábio César; RIGO, José Rogério. Biopolítica: reflexões a partir de Giorgio Agamben. (In) Anais do Congresso Internacional das Faculdades EST. São Leopoldo: EST, v. 1, 2012, p.1154-1161. Disponível em: file:///C:/Users/gerso/Downloads/28-770-1-PB.pdf. Acesso em 20 abril 2017.

KELSEN, Hans. Teoria Geral do Direito e do Estado. Trad. Luis Carlos Borges. São Paulo: Martins Fontes, 2005. . Teoria Pura do Direito. Trad. de João Baptista Machado. 6. ed. Coimbra: Arménio Amado, 1984.

LEVI, Primo. É isto um homem? Trad. De Luigi Del Re. Rio de Janeiro: Rocco, 1988.

LOCKE, John. Dois tratados sobre o governo. São Paulo: Martins Fontes, 1998.

MARX, Karl. A Questão Judaica. 2. Ed. São Paulo: Moraes, 1991.

MIR PUIG, Santiago. El Derecho Penal en el Estado Social y Democrático de Derecho. Barcelona: Ariel, 1994

MOREIRA, Vital. Fundamentos da Constituição. Coimbra: Coimbra, 1991.

PÉREZ LUÑO, Antonio Enrique. La tercera generación de derechos humanos. Madrid: Tecnos, 1990. 
. Teoría del Derecho: una concepción de la experiencia jurídica. 5 ed. Madrid: Tecnos, 2006.

PRADO, Luiz Regis. Bem jurídico-penal e Constituição. São Paulo, RT, 1996.

. Princípios da dignidade da pessoa e humanidade das penas na Constituição Federal de 1988. Disponível em: http://www.professorregisprado.com/resources/Artigos. Acesso em: 17 abril, 2017.

. Tratado de Direito Penal brasileiro: parte geral: volume 1. São Paulo: Revista dos Tribunais, 2014.

SANTOS, Fernando Ferreira dos. Princípio constitucional da dignidade da pessoa humana. Fortaleza: IBDC - Celso Bastos, 1999.

. Questões de Direito Público. São Paulo: Saraiva, 1997.

ROUSSEAU, Jean-Jacques. O contrato Social. Trad. Pietro Nasseti. 20. ed. São Paulo: Martin Claret, 2001.

RUIZ, Castor M. M. Bartolomé. A exceção jurídica na biopolítica moderna. Disponível em: http://www.ihuonline.unisinos.br/index.php?option=com_content\&view=article\&id=4044\&secao $=371$. Acesso em: 18 abril, 2017.

SANTOS, Fernando Ferreira dos. Princípio constitucional da dignidade da pessoa humana. Fortaleza: IBDC - Celso Bastos, 1999.

SÉNECA. El igualitarismo estoico, Séneca y la dignidad de los esclavos. Disponível em: http://www.cedt.org/seneca.htm. Acesso em: 17 abril, 2017.

SMITH, Adam. Inquérito sobre a natureza e as causas da riqueza das nações. Trad. de Armandina Henriques Puga e Marilia Alves Pereira. Lisboa: Fundação Calouste Gulbenkian, 2006, v. 1.

WELZEL, Hans. Introducción a la filosofia del Derecho: derecho natural y justicia material. Trad. Felipe González Vicén. Madrid: Aguilar, 1971. 
Trabalho recebido em 27 de julho de 2018

Aceito em 19 de setembro de 2018 